inOedia $\quad \begin{aligned} & \text { InMedia } \\ & \text { The French Journal of Media Studies }\end{aligned}$

$4 \mid 2013$

Exploring War Memories in American Documentaries

\title{
Isabelle Rigoni and Eugenie Saitta (eds), Mediating Cultural Diversity in a Globalized Public Space
}

New York: Palgrave Macmillan, 2013, 192 pages

Christopher Ali

\section{CpenEdition}

\section{Journals}

Electronic version

URL: http://journals.openedition.org/inmedia/712

DOI: 10.4000/inmedia.712

ISSN: 2259-4728

Publisher

Center for Research on the English-Speaking World (CREW)

Electronic reference

Christopher Ali, «Isabelle Rigoni and Eugenie Saitta (eds), Mediating Cultural Diversity in a Globalized Public Space », InMedia [Online], 4 | 2013, Online since 12 November 2013, connection on 24

September 2020. URL : http://journals.openedition.org/inmedia/712 ; DOI : https://doi.org/10.4000/ inmedia. 712

This text was automatically generated on 24 September 2020

(C) InMedia 


\section{Isabelle Rigoni and Eugenie Saitta (eds), Mediating Cultural Diversity in a Globalized Public Space}

New York: Palgrave Macmillan, 2013, 192 pages

Christopher Ali

\section{REFERENCES}

Isabelle Rigoni and Eugenie Saitta (eds), Mediating Cultural Diversity in a Globalized Public Space, New York: Palgrave Macmillan, 2013, 192 pages 
1 In 2000, Curran and Park published an influential edited collection with a clear aim: to "de-westernize media studies". In doing so, they put a term to what many had believed for quite some time: we need to look beyond the west. The theme of dewesternizing media studies certainly caught on, as did two related areas to Curran and Park's call: the study of diasporic and ethnic minority media both within western countries, and also as examples of the global circulation and mobility of texts, genres, people and capital (Appadurai, 1996). While Curran and Park's goal was to emphasize research from places outside the "Anglo-American orbit" (11), these parallel interests on transnational, diasporic, 'ethnic', minority, and migrant media productions have become equally important sites for

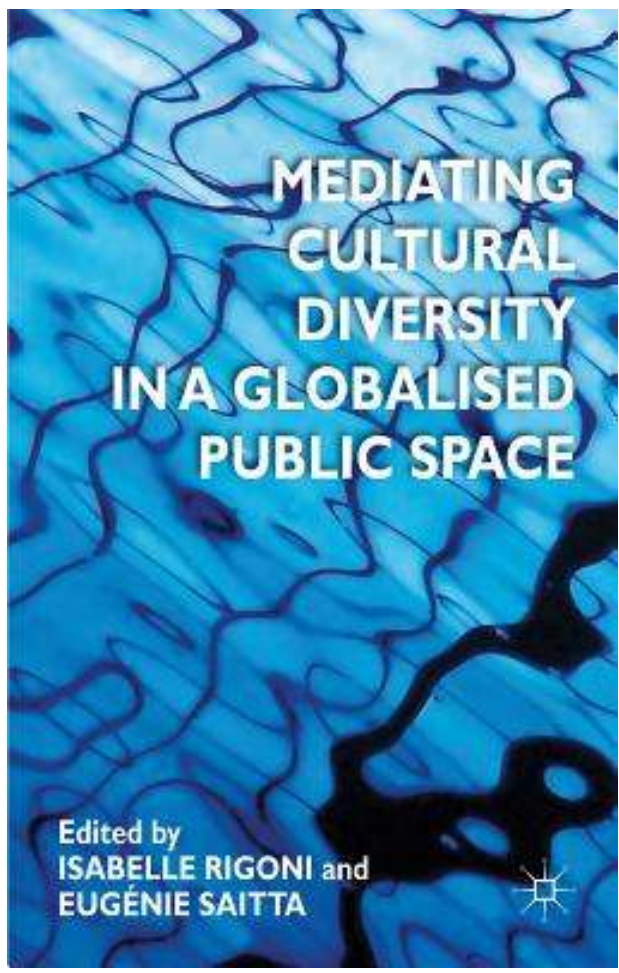
scholarly inquiry. Diasporic media are seminal communicatory practices that connect migrant and mobile communities with their territorial homes, and have been of interest to scholars for decades (i.e. Nacify, 1993; Karim, 2003; Husband, 2000). In the spirit of de-westernizing media studies, the case studies brought together by Rigoni and Saitta are important contributions to understanding cultural diversity in global media practices.

2 The book focuses on the production of 'ethnic' and minority media and communicatory practices within the global circulation of ideas and texts, and the "widespread democratization of access to technological tools," (1). The chapters emerged primarily from a conference on Alternative Self-Representation held in Paris in March 2010. The overall aim of both the conference and the book is to position ethnic media practitioners as vibrant and productive agents within the production of media and culture (2). That said the editors make four critical assertions in their introduction that tempers any assumption of myopic celebration of ethnic media as unquestionably emancipatory and democratic. First, they recognize that acknowledging the democratization of technology does not mean "celebrating the new per se" (2). In other words, old and new media are equal partners in ethnic media production practices. Moreover, the digital divide, while slowly abating, still resonates within more countries than where it is being bridged. The Internet, therefore, has limits. Second, they observe that ethnic media is not a singular, homogeneous or hermetically sealed genre of texts, but are diverse and complex. Third, they remind the reader that ethnic media is not by default "subversive by the very fact of their ethnic identity" (3). Fourth, they contend that it is false to position 'ethnic' and 'mainstream' media as diametrically opposed. To do so, "would be to deny the complexity of journalism and the relationships which exist between different types of media" (3). 
3 While not enumerated as such, a fifth critical assertion is the deliberate choice to focus on "mobility" rather than on "migration" in assessing diasporic and ethnic media (5). This important distinction recognizes that with the rise in access to ICTs, "individuals no longer have to cross borders in order to create and maintain links with others across the globe" (5). It is also a commentary on the role of 'presence' and 'absence' in media production and consumption. They suggest the notion of "co-presence" to emphasize that "circulation is no longer just about physical displacement within space; without being geographically mobile, without even being a migrant in the strictest sense, an individual can nonetheless be part of a "culture of mobility"' (6, quoting Rigoni, forthcoming). Mobility, therefore, has become a defining feature of migratory and ethnic media practices.

4 Not only are these assertions useful for framing the critical disposition of the chapters, but they are also transportable to other scholarly domains not necessarily related to ethnic minority media. These critical assertions also anticipate the general argument of the book that "ethnic minority media, insofar as they constitute partial public spaces, do not always in fact succeed in appearing as tools of counter-hegemony, despite their frequently stated desire to be seen as alternative media" (9). Echoing this pluralistic understanding of ethnic media, the authors position "public space" not as a fixed concept, but rather one of "collective reconstruction" - a malleable space impacted by hegemonic ideology (9). This collection thus offers a critical perspective on ethnic media which recognizes its normative value, but which is not prepared to uncritically celebrate its existence.

5 Mediating Cultural Diversity is divided in three sections, with Rigoni and Saitta's introduction providing the central themes and overall argument. Part One's two case studies inquire as to "The Internet as a Space of Super-Diversity?" Both chapters celebrate the Internet as a space and place for diasporic communication and representation. Bailey's chapter uses Deuleuze and Guattari's conceptual framework of rhizomatic and arbolic thinking to argue that the Internet is useful for the facilitation of rhizomatic spaces for ethnic and diasporic groups (23). In other words, the Internet can facilitate a "smooth space" of anti-hierarchical, "non-linear, anarchic and nomadic" relationships (23). Through a case study of the participatory website "African Women in Europe," Bailey suggests that this site represents “'speaking spaces' for diasporic and ethnic groups that potentially strengthen groups through their selfrepresentation, interconnected stories, and create alternative public spheres that might interact with mainstream spheres to enable them to sustain the articulation of cultural difference" (31). Similarly upholding the role of the Internet to facilitate democratic discourse, Nedelcu's chapter focuses on the online response to campaigns of racial and ethnic prejudice in Switzerland against Romanian migrants, and the online transnational mobilization of diasporic Romanians. Nedelcu argues that the development of ICTs and the Internet in particular offers both "space for democratic expression of migrant minorities" through the facilitation of "netizenship" - a new "form of participation and active citizenship" - and "create[s] basic conditions for collective agency, gathering migrant and non-migrant populations across borders" (48-49).

6 Contrasting with these rather favourable views of the relationship between migrant communities and online spaces, Part Two offers a more critical perspective. Titley's chapter focuses on the shifting discourse from "multiculturalism" to "diversity" within 
certain countries in Europe (especially Ireland) to avoid what he sees as the negative connotations of the discourse of "multiculturalism" (61). Navaz and Ferrer investigate the difficulties of migrant Latin American journalists in Spain and note how further research needs to interrogate the "tensions between market and citizenship" rather than take them for granted (90). Of all the chapters, however, it is arguably Bozdag, Hepp and Suna's that represents the keystone of the book. The authors offer a conceptual and methodological overview of diasporic media focusing on the concept of "diasporic networking," and ask whether "diasporic media really offer an 'alternative' space" (96). Importantly, the authors offer a definition of "diasporic media," something that is absent and perhaps even lacking in other chapters. They define the practice as "the media that are produced by and for migrants and deal with issues that are of specific interest for the members of diasporic communities," (97). They argue that diasporic media need to be understood within the spectrum of media production rather than isolated and studied on its own. This suggests a more complex ecological understanding of media and cultural production. Scholars also need to be reminded that ethnic media are only used for the purposes of establishing migrant "public spheres" but also for entertainment (110-11). They conclude that the lexicon of "diasporic media" may be more useful than that of "alternative media" or "alternative public spheres" since, while they are not homogeneous, they are nevertheless "orientated towards the diasporic community in a thematic-organizational sense and are on that account building a focus for the networking of diasporas" (111).

While offering a conceptual understanding of the place of diasporic media within a media ecosystem, Bozdag, Hepp and Suna also bring to the fore a relationship that could use more robust discussion: the relationship and boundaries between "diasporic media" and what scholars have called "community media" (Howley, 2005), "radical media" (Downing, 2001), "alternative media" (Atton, 2002) or "citizens' media" (Rodriguez, 2001). What is the relationship between these media practices, and are they best described as separate entities or as porous categories? Is there benefit to thinking in terms of bridges between these supposedly democratic media practices or are they best left apart?

8 The final part of the book interrogates the role of diasporic media as counterhegemonic practices. Thussu's chapter, for instance, argues that Bollywood simultaneously disrupts "U.S. cultural hegemony" and creates "its own version of hegemony" (119). Ferron's chapter comes closest to addressing the question posed in the previous paragraph: the relationship between diasporic and community media. $\mathrm{He}$ positions minority media as an iteration of "alternative media," using case studies of Mexican neo-Zapatista indigenous media, and "Palestinian Arab media in IsraelPalestine" (137). While attempting to define alternative media Ferron sees its various conceptualizations (community, alternative, radical, etc...) as synonymous, and positions certain examples of ethnic minority media in Mexico and Israel as examples of "alternative media". Tempering this inclusiveness however, he also makes note of the contentious debate between indigenous media and community media in Mexico. He concludes by reinforcing several themes in the book: that alternative, and ethnic minority media cannot be understood in isolation from "mainstream media," that alternative media is not a homogeneous media practice, and that "community, ethnic minority, alternative media do not necessarily have a democratic impact on the public space" (150). He suggests thinking about ethnic minority media and alternative media 
through a more nuanced perspective of "civil society media" and "social movement media" to better encapsulate the political agendas of these practices.

Through an analysis of the "Black African Press in the United Kingdom" Ogunyemi's chapter concludes the book by restating one of its central theses: that ethnic media do not always represent hegemonic resistance or alternative politics, but rather can also serve to replicate mainstream media practices. Here, Britain's black African press serves to "replicate the sourcing routines of its mainstream counterparts by monitoring the same official channels" (165). The author concludes however that such an elite discourse reflects editors' desire to promote underreported ethnic minority stories, rather than on promoting alternative voices. This highlights an existential dilemma not only within ethnic minority media, but "alternative," "community," "citizens" or "radical" media more generally: to replicate mainstream practices and thereby gain potential visibility, or to promote alternative and internal voices and aim to strengthen ties to existing communities.

If one were to search for a place where this research could be expanded it would be in the area of probing the conceptual boundaries of migrant, diasporic or ethnic media, and the relationships with other participatory media practices such as alternative, community, radical, or citizens' media. Ferron's chapter along with Bozdag, Hepp and Suna begin such a conversation about building bridges within culturally diverse media within a globalized public space. Specifically, their research anticipates the question: what are the benefits and shortcomings of separating these practices, empirically, methodologically, and conceptually? Such questioning represents the strength of the book, rather than a weakness, because it opens up avenues for inquiry and interrogation. As the authors constantly remind the reader, diasporic and ethnic media are not static, singular or homogenous practices but rather complex and dynamic activities, and their contributions need to be understood as such.

Back in 2000, Curran and Park argued, "media studies will benefit from developing a wider comparative perspective" (15). This book certainly contributes to this benefit, and offers unique empirical and theoretical contributions to the study of ethnic media. While not for the uninitiated reader, each chapter is well positioned to be added to advanced undergraduate or graduate syllabi on diasporic, migrant, mobile, ethnic or transnational media, as they are self-contained, and offer a valuable contribution to this important and dynamic field.

\section{BIBLIOGRAPHY}

Appadurai, A. Modernity at Large: Cultural Dimensions of Globalization. Minneapolis: University of Minnesota Press, 1996.

Atton, C. Alternative Media. Thousand Oaks: Sage, 2002.

Curran, J. \& Park, M.J. “Beyond Globalization Theory”. In De-Westernizing Media Studies, edited by J. Curran and M.J. Park, 3-18. London: Routledge, 2000. 
Downing, J. Radical Media: Rebellious Communication and Social Movements. Thousand Oaks: Sage, 2001.

Howley, K. Community Media: People, Places, and Communication Technologies. Cambridge: Cambridge University Press, 2005.

Husband, C. "Media and the Public Sphere in Multi-Ethnic Societies". In Ethnic Minorities and the Media, edited by S. Cottle, 199-214. Buckingham: Open University Press, 2000.

Karim, K.H. “Mapping Diasporic Mediascapes”. In The Media of Diaspora, edited by K. H. Karim, 1-18. London: Routledge, 2003.

Nacify, H. The Making of Exile Cultures: Iranian Television in Los Angeles. Minneapolis: University of Minnesota Press, 1993.

Rodriguez, C. Fissures in the Mediascape: An International Study of Citizens' Media. Cresskill: Hampton Press, 2001.

\section{AUTHOR}

\section{CHRISTOPHER ALI}

University of Pennsylvania 